\title{
Kineosporia babensis sp. nov., isolated from plant litter in Vietnam
}

\author{
Correspondence \\ Yayoi Sakiyama \\ sakiyama-yayoi@nite.go.jp
}

\author{
Yayoi Sakiyama, ${ }^{1}$ Nguyen K. N. Thao, ${ }^{2}$ Nguyen M. Giang, ${ }^{2}$ Shinji Miyadoh, ${ }^{1}$ \\ Duong V. Hop ${ }^{2}$ and Katsuhiko Ando ${ }^{1}$
${ }^{1}$ NITE Biological Resource Center (NBRC), National Institute of Technology and Evaluation (NITE), Chiba 292-0818, Japan
${ }^{2}$ Institute of Microbiology and Biotechnology (IMBT), Vietnam National University, Hanoi (VNUH), Hanoi, Vietnam

\begin{abstract}
Three actinomycetes, designated strains VN05A0342, VN05A0351 and VN05A0415 ${ }^{\top}$, were isolated from plant-litter samples collected in the north of Vietnam and examined in a polyphasic taxonomic study. Phylogenetic analysis based on the 16S rRNA gene sequences showed that these isolates were most closely related to the type strain of Kineosporia mikuniensis (98.5\% sequence similarity). Morphological properties (the formation of spore domes and motile spores) and chemotaxonomic data supported the assignment of the three isolates to the genus Kineosporia. The isolates all contained the following: meso-diaminopimelic acid in the peptidoglycan (with small amounts of the $\mathrm{LL}$ isomer); ribose, mannose, galactose and glucose as the whole-cell sugars; MK- $9\left(\mathrm{H}_{4}\right)$ as the predominant isoprenoid quinone; $\mathrm{C}_{18: 1}$ and $\mathrm{C}_{16: 0}$ as the major cellular fatty acids; and phosphatidylcholine, phosphatidylglycerol, diphosphatidylglycerol and phosphatidylinositol as the phospholipids. The high DNA-DNA relatedness $(>71 \%)$ among the three isolates showed that they represented a single species. On the other hand, the DNA-DNA relatedness between the novel isolates and all type strains of Kineosporia species was less than $46 \%$. The physiological properties of our isolates were distinct from those of all of the Kineosporia species with validly published names, e.g. decomposition of L-tyrosine and aesculin and the utilization of raffinose and D-arabitol. Therefore, strains VN05A0342, VN05A0351 and VN05A0415 ${ }^{\top}$ represent a novel species of the genus Kineosporia, for which the name Kineosporia babensis sp. nov. is proposed. The type strain is VN05A0415 ${ }^{\top}$ $\left(=\right.$ VTCC$-\mathrm{A}-0961^{\top}=$ NBRC $\left.104154^{\top}\right)$.
\end{abstract}

The genus Kineosporia was first reported by Pagani \& Parenti (1978). The genus was described as comprising organisms that form sporangia (each containing a single zoospore) at the edge of the substrate mycelium and contain only LL-diaminopimelic acid (LL-A $\mathrm{A}_{2} \mathrm{pm}$ ) in the peptidoglycan. Subsequently, Itoh et al. (1989) and Kudo et al. (1998) emended the description of the genus on the basis of the presence of both LL- $\mathrm{A}_{2} \mathrm{pm}$ and meso- $\mathrm{A}_{2} \mathrm{pm}$ and the similarity of the colonial morphology to 'spore-dome actinomycetes' (Willoughby, 1969). At the time of writing, the genus Kineosporia comprises five species with validly

Abbreviation: $\mathrm{A}_{2} \mathrm{pm}$, diaminopimelic acid.

The GenBank/EMBL/DDBJ accession numbers for $16 \mathrm{~S}$ rRNA gene sequences of strains VN05A0415 ${ }^{\top}, \mathrm{VN} 05 A 0342$ and VN05A0351 are AB377116, AB377118 and AB377119, respectively.

Cultural characteristics and fatty acid compositions of strains VN05A0342, VN05A0351 and VN05A0415 ${ }^{\top}$ and all of the type strains of Kineosporia species are available as supplementary material with the online version of this paper. published names. In this study, we used a polyphasic approach to classify three novel actinomycete isolates. On the basis of the data from this study, these three isolates represent a novel species of the genus Kineosporia.

The samples of plant litter were collected in 2005 from the mountainside at Ba Be National Park, Bac Kan Province, in northern Vietnam. The samples were dried at room temperature for 5-7 days and then inoculated using the rehydration-centrifugation method (Hayakawa et al., 2000) on humic acid-vitamin agar (Hayakawa \& Nonomura, 1987) containing nalidixic acid $\left(20 \mathrm{mg} \mathrm{l}^{-1}\right)$ and kabicidin $\left(0.75 \mathrm{mg} \mathrm{l}^{-1}\right)$. Our isolates, designated VN05A0342, VN05A0351 and VN05A0415 ${ }^{\mathrm{T}}$, were isolated after incubation for more than 10 days at room temperature.

Strains VN05A0342, VN05A0351 and VN05A0415 ${ }^{\mathrm{T}}$ were incubated on yeast extract-soluble starch medium (YS medium; $2 \mathrm{~g}$ yeast extract, $10 \mathrm{~g}$ soluble starch and $15 \mathrm{~g}$ agar $1^{-1}$; pH 7.3) at $28{ }^{\circ} \mathrm{C}$ for $10-14$ days. The orange colonies that formed appeared moist and were raised, like 


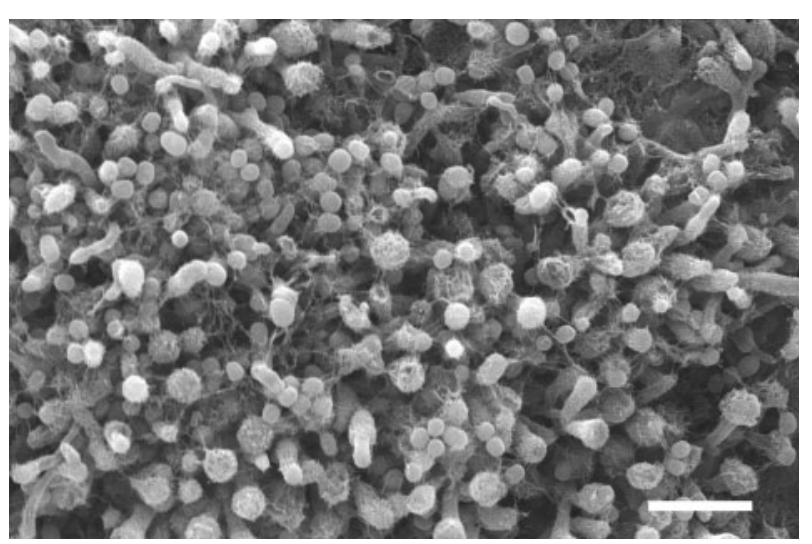

Fig. 1. Scanning electron micrograph of strain $\mathrm{VN} 05 \mathrm{~A} 0415^{\top}$ grown on water agar for 10 days at $28^{\circ} \mathrm{C}$. Bar, $5 \mu \mathrm{m}$.

'spore-dome actinomycetes' (Willoughby, 1969), from the surface of the YS medium. Aerial mycelium was absent. The spore-domes were formed by bunches of single spores borne on sporophores similar to those described by Itoh et al. (1989). Scanning electron microscopy showed that the spores were globular and/or ovoid $(1.0-2.0 \mu \mathrm{m}$ in diameter) with a smooth surface. The spores seemed to be enveloped in a club-shaped sporangium (Fig. 1), as reported by Pagani \& Parenti (1978). Light-microscopic observation of cells suspended in phosphate buffer ( $\mathrm{pH} 7.0,1 \mathrm{mM})$ showed the spores to be motile. The cultural characteristics of our isolates and all type strains of Kineosporia species were observed on ISP media 2-7 (Shirling \& Gottlieb, 1966) and YS medium after incubation at $28{ }^{\circ} \mathrm{C}$ for 3 weeks (see Supplementary Table S1, available in IJSEM Online). Our isolates and all type strains of Kineosporia species showed good growth on YS medium, ISP 2 and ISP 3. Only our isolates and the type strain of Kineosporia aurantiaca grew on ISP 6.

For the chemotaxonomic analysis, biomass from each strain was obtained by centrifugation and lyophilization after incubation in yeast extract-glucose broth (10 g yeast extract and $10 \mathrm{~g}$ glucose $1^{-1}$; pH 7.3) for 7-10 days at $28{ }^{\circ} \mathrm{C}$. The whole-cell sugars, isoprenoid quinones, phospholipids and cellular fatty acids were analysed as described by Staneck \& Roberts (1974), Minnikin et al. (1984) and Tamura et al. (1994). The $\mathrm{A}_{2} \mathrm{pm}$ isomer in the peptidoglycan was analysed as described by Nozawa et al. (2007). Kudo et al. (1998) reported that Kineosporia strains exhibit heterogeneity of the $\mathrm{A}_{2} \mathrm{pm}$ isomer because of the presence of different isomers in mycelium and spores. Our isolates, strains VN05A0342, VN05A0351 and VN05A0415 ${ }^{\mathrm{T}}$, also contained both of the $\mathrm{A}_{2} \mathrm{pm}$ isomers: a small amount of LL$\mathrm{A}_{2} \mathrm{pm}$ was present, but the main isomer was meso- $\mathrm{A}_{2} \mathrm{pm}$. The whole-cell sugars were ribose, mannose, galactose and glucose. The isoprenoid quinone was $\mathrm{MK}-9\left(\mathrm{H}_{4}\right)$. Phosphatidylcholine, phosphatidylglycerol, diphosphatidylglycerol and phosphatidylinositol were detected, but phosphatidylethanolamine and phosphatidyl- $N$-methylethanolamine were absent. The major cellular fatty acids were $\mathrm{C}_{18: 1}$ and $\mathrm{C}_{16: 0}$, but iso- and/or anteiso-branched fatty acids were not detected (Supplementary Table S2). The chemotaxonomic data for our isolates were consistent with the characteristics described for the genus Kineosporia.

The DNA was extracted as described by Marmur (1961) and Saito \& Miura (1963), but with a slight modification: after lysis, we used $20 \%$ SDS and protease $\mathrm{K}$ to denature proteins, and phenol/chloroform/isoamyl alcohol $(25: 24: 1$, by vol.) to remove denatured proteins. $16 \mathrm{~S}$ rRNA gene sequences were analysed as described by Tamura \& Hatano (2001). Sequence analysis was performed with an ABI Prism BigDye Terminator cycle sequencing kit (PE Applied Biosystems) and an automatic DNA sequencer (model 3130 Genetic Analyzer; PE Applied Biosystems). The CLUSTAL_X program (Thompson et al., 1997) was used to align the 16S rRNA gene sequences with corresponding sequences (available in the GenBank/EMBL/ DDBJ databases) from all of the type strains of Kineosporia species and some related actinomycetes of the suborder Frankineae. Phylogenetic trees were constructed using the neighbour-joining (Saitou \& Nei, 1987) and maximumparsimony (Kluge \& Farris, 1969) methods. The topology of the trees was evaluated by means of bootstrap analysis based on 1000 replicates (Felsenstein, 1985). DNA-DNA hybridization was carried out using the method of Ezaki et al. (1989). The G $+\mathrm{C}$ content of the DNA was determined using the method of Mesbah et al. (1989).

Phylogenetic analysis based on 16S rRNA gene sequences revealed that our isolates and all type strains of the genus Kineosporia formed a monophyletic cluster (Fig. 2). The cluster had bootstrap support in both neighbour-joining

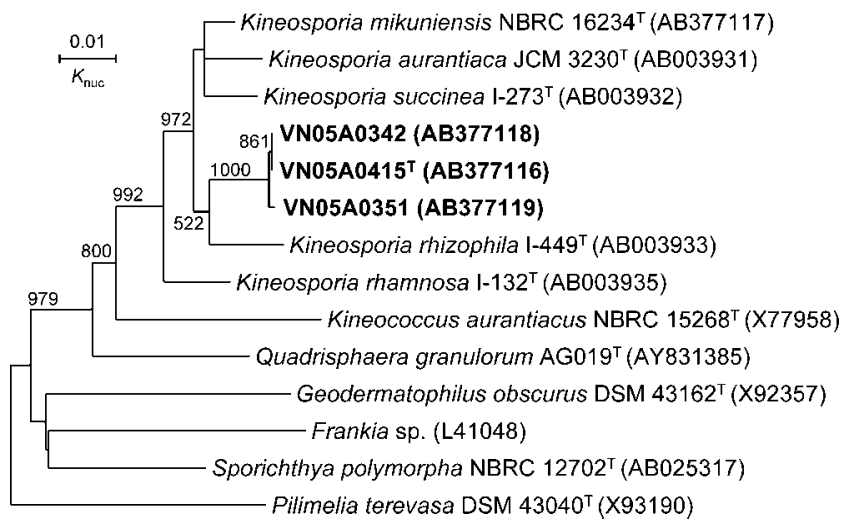

Fig. 2. Neighbour-joining phylogenetic tree, based on 16S rRNA gene sequences, for strains VN05A0342, VN05A0351 and VN05A0415 ${ }^{\top}$, all type strains of Kineosporia species and some actinomycetes in suborder Frankineae. Numbers at branch points are confidence limits estimated by means of bootstrap analysis based on 1000 replicates; only values $>500$ are presented. Bar, $0.01 K_{\text {nuc }}$ in nucleotide sequences. 
Table 1. DNA-DNA hybridization among strains VN05A0342, VN05A0351 and VN05A0415 and all type strains of Kineosporia species

\begin{tabular}{|lrrrrrrrr|}
\hline \multirow{2}{*}{ Source of unlabelled DNA } & \multicolumn{7}{c|}{ DNA-DNA relatedness (\%) } & with labelled DNA from: \\
\cline { 2 - 10 } & \multicolumn{1}{c}{$\mathbf{1}$} & \multicolumn{1}{c}{$\mathbf{2}$} & \multicolumn{1}{c}{$\mathbf{3}$} & $\mathbf{4}$ & $\mathbf{5}$ & $\mathbf{6}$ & $\mathbf{7}$ & $\mathbf{8}$ \\
\hline 1. VN05A0342 & 100 & 92 & 108 & 13 & 19 & 23 & 23 & 30 \\
2. VN05A0351 & 82 & 100 & 98 & 13 & 21 & 21 & 23 & 30 \\
3. VN05A415 & 76 & 71 & 100 & 13 & 21 & 26 & 25 & 32 \\
4. K. aurantiaca NBRC $14067^{\mathrm{T}}$ & 20 & 26 & 17 & 100 & 19 & 20 & 14 & 28 \\
5. K. rhamnosa NBRC $16231^{\mathrm{T}}$ & 5 & 7 & 6 & 9 & 100 & 8 & 7 & 11 \\
6. K. succinea NBRC $16232^{\mathrm{T}}$ & 28 & 40 & 21 & 16 & 22 & 100 & 19 & 23 \\
7. K. rhizophila NBRC 16233 & 34 & 46 & 27 & 17 & 22 & 25 & 100 & 33 \\
8. K. mikuniensis NBRC $16234^{\mathrm{T}}$ & 28 & 33 & 19 & 15 & 19 & 19 & 22 & 100 \\
\hline
\end{tabular}

and maximum-parsimony phylogenetic trees. Although our isolates and the type strain of Kineosporia rhizophila formed a clade in the phylogenetic tree, the tree topology was not supported by bootstrapping analysis (52.2\%). Our isolates shared 16S rRNA gene sequence similarity of 99.8$100 \%$. The nucleotide sequence similarity between our isolates and all type strains of the genus Kineosporia ranged from 96.1 to $98.5 \%$. Our isolates showed the greatest similarity with respect to the type strain of Kineosporia mikuniensis.

DNA-DNA hybridization among our isolates and all type strains of Kineosporia species was determined (Table 1). The DNA relatedness among strains VN05A0342, VN05A0351 and VN05A0415 ${ }^{\mathrm{T}}$ ranged from 71 to $108 \%$. Consequently, our isolates were identified as representing a single species. The DNA relatedness between our isolates and all Kineosporia type strains was less than $46 \%$, being below the $70 \%$ cut-off point recommended for the delineation of genomic species (Wayne et al., 1987). Therefore, strains VN05A0342, VN05A0351 and VN05A0415 ${ }^{\mathrm{T}}$ were different from all type strains of Kineosporia species. The $\mathrm{G}+\mathrm{C}$ contents of their DNAs were in the range $69-70 \mathrm{~mol} \%$.

Physiological and biochemical characteristics of our isolates were tested after incubation at $28{ }^{\circ} \mathrm{C}$ for 3 weeks. $\mathrm{NaCl}$ tolerance was examined on YS medium prepared with $0,1,2,3,4,5$ and $6 \% \mathrm{NaCl}(\mathrm{w} / \mathrm{v})$. ISP 8 (Gordon \& Mihm, 1957) was used to test for nitrate reduction. Decomposition of urea was determined on Christensen urea agar containing 2\% urea (Gordon et al., 1974). Degradation of casein and other compounds (final concentration $0.5 \%$ ) was determined using nutrient agar as the basal medium (Gordon et al., 1974). Aesculin hydrolysis and utilization of citrate were examined according to the methods of Gordon et al. (1974). The utilization of other carbohydrates was tested on yeast nitrogen base without amino acids (Bacto), as described by Goodfellow (1971). The utilization of organic acids was determined on a medium composed of $\left(1^{-1}\right) 1.0 \mathrm{~g}$ $\mathrm{NH}_{4} \mathrm{NO}_{3}, 1.0 \mathrm{~g} \mathrm{KH}_{2} \mathrm{PO}_{4}, 0.5 \mathrm{~g} \mathrm{MgSO}_{4} .7 \mathrm{H}_{2} \mathrm{O}$ and $0.2 \mathrm{~g}$ $\mathrm{KCl}$ (pH 7.2), containing $20 \mathrm{ml} 0.04 \%$ phenol red and supplemented with $1 \%$ organic salts or $0.2 \%$ benzoic acid. An acid-production test was performed on basal medium composed of $\left(1^{-1}\right) 10 \mathrm{~g}$ peptone and $5 \mathrm{~g} \mathrm{NaCl}(\mathrm{pH} 7.2)$ plus the test compound (1\%).

The features that served to differentiate strains VN05A0342, VN05A0351 and VN05A0415 ${ }^{\mathrm{T}}$ from known species of the genus Kineosporia were the decomposition of L-tyrosine and aesculin and the utilization of raffinose and D-arabitol (Table 2).

On the basis of the results of the polyphasic taxonomic study presented here, strains VN05A0342, VN05A0351 and $\mathrm{VN} 05 \mathrm{~A} 0415^{\mathrm{T}}$ represent a novel species of the genus Kineosporia, for which the name Kineosporia babensis sp. nov. is proposed.

\section{Description of Kineosporia babensis sp. nov.}

Kineosporia babensis (ba.ben'sis. N.L. fem. adj. babensis referring to Ba Be National Park, Vietnam, from which the first strains were isolated).

The orange-coloured colonies grow prolifically on YS medium and appear moist and raised. Each raised colony produces clusters of single spores. The spore surface is smooth and the spores are globular and/or ovoid (1.0$2.0 \mu \mathrm{m}$ in diameter). Grows at $10-28{ }^{\circ} \mathrm{C}$, but not at 5 or $37{ }^{\circ} \mathrm{C}$. Grows in the presence of $3 \% \mathrm{NaCl}(\mathrm{w} / \mathrm{v})$. Melanin is not produced on ISP 6 or ISP 7. Negative for nitrate reduction. Decomposes aesculin, arbutin, casein, testosterone, L-tyrosine and urea, but not adenine, hypoxanthine or xanthine. Utilizes carbon sources such as L-arabinose, cellobiose, D-fructose, D-galactose, D-glucose, myo-inositol, D-lactose, maltose, D-mannitol, melezitose, melibiose, raffinose, L-rhamnose, D-ribose, salicin, D-sorbitol, starch, sucrose, trehalose and D-xylose, but not adonitol, Darabitol, dulcitol, methyl $\alpha$-D-glucoside, L-sorbose or xylitol. Utilizes organic acids such as fumarate, malate and succinate, but not benzoate, mucate, oxalate or Ltartrate. Produces acid from L-arabinose, cellobiose, Dfructose, D-galactose, D-glucose, L-rhamnose, sucrose and D-xylose, but not from adonitol, i-erythritol, myo-inositol, melezitose and D-sorbitol. The cell wall contains major 
Table 2. Differential physiological characteristics among strains VN05A0342, VN05A0351 and VN05A0415 ${ }^{\top}$ and type strains of all Kineosporia species

Strains: 1, VN05A415 ${ }^{\mathrm{T}}$ (strains VN05A0342 and VN05A0351 showed identical results unless indicated); 2, K. aurantiaca NBRC $14067^{\mathrm{T}} ; 3$, K. rhamnosa NBRC $16231^{\mathrm{T}}$; 4, K. succinea NBRC $16232^{\mathrm{T}} ; 5, K$. rhizophila NBRC $16233^{\mathrm{T}}$; 6, K. mikuniensis NBRC $16234^{\mathrm{T}}$. Data for reference type strains were taken from Kudo et al. (1998).

\begin{tabular}{|c|c|c|c|c|c|c|}
\hline Strain & 1 & 2 & 3 & 4 & 5 & 6 \\
\hline \multicolumn{7}{|l|}{ Decomposition of: } \\
\hline L-Tyrosine & $\begin{array}{l}+ \text { (brown } \\
\text { pigment) }\end{array}$ & - & - & - & - & - \\
\hline Aesculin & + & + & - & - & - & - \\
\hline $\mathrm{NaCl}$ tolerance $(\%, \mathrm{v} / \mathrm{v})$ & $4^{*}$ & $<3$ & $<2$ & $<5$ & $<5$ & $<1$ \\
\hline \multicolumn{7}{|l|}{ Utilization of: } \\
\hline Raffinose & + & - & \pm & - & + & - \\
\hline D-Arabitol & - & + & - & + & + & + \\
\hline
\end{tabular}

${ }^{*}$ Strain VN05A0351 tolerated $3 \% \mathrm{NaCl}$ but not $4 \%$.

amounts of meso- $\mathrm{A}_{2} \mathrm{pm}$ and small amounts of $L L-\mathrm{A}_{2} \mathrm{pm}$. The whole-cell sugars are ribose, mannose, galactose and glucose. The predominant menaquinone is MK- $9\left(\mathrm{H}_{4}\right)$. The phospholipids are phosphatidylcholine, phosphatidylglycerol, phosphatidylglycerol and phosphatidylinositol. The major cellular fatty acids are $\mathrm{C}_{18: 1}$ and $\mathrm{C}_{16: 0}$. The DNA $\mathrm{G}+\mathrm{C}$ content is $69-70 \mathrm{~mol} \%$.

The type strain, VN05A0415 ${ }^{\mathrm{T}}\left(=\mathrm{VTCC}-\mathrm{A}-0961^{\mathrm{T}}=\mathrm{NBRC}\right.$ $\left.104154^{\mathrm{T}}\right)$, was isolated from plant litter.

\section{Acknowledgements}

This work was conducted as a joint research project between the Department of Biotechnology, NITE (NITE-DOB), Japan, and the IMBT, VNUH, Vietnam. The authors are grateful to Dr Tomohiko Tamura, Ms Kozue Anzai, Mr Nobuyuki Goto, Dr Misa Otoguro, Dr Hideki Yamamura, Ms Kayo Tsuruya, Mr Shinpei Ino, Ms Ayako Hashimoto, Dr Takuji Nakashima (NITE), Dr Dinh Thuy Hang, Dr Dao Thi Luong (IMBT, VNUH) and all members at IMBT for their kind help and advice. We also thank Dr Yuriko Nozawa (Taisho Pharmaceutical Co., Ltd) for analysis of the $\mathrm{A}_{2} \mathrm{pm}$ isomer by LC-MS.

\section{References}

Ezaki, T., Hashimoto, Y. \& Yabuuchi, E. (1989). Fluorometric deoxyribonucleic acid-deoxyribonucleic acid hybridization in microdilution wells as an alternative to membrane filter hybridization in which radioisotopes are used to determine genetic relatedness among bacterial strains. Int J Syst Bacteriol 39, 224-229.

Felsenstein, J. (1985). Confidence limits on phylogenies: an approach using the bootstrap. Evolution 39, 783-791.

Goodfellow, M. (1971). Numerical taxonomy of some nocardioform bacteria. J Gen Microbiol 69, 33-80.

Gordon, R. E. \& Mihm, J. M. (1957). A comparative study of some strains received as nocardiae. J Bacteriol 73, 15-27.
Gordon, R. E., Barnett, D. A., Handerhan, J. E. \& Pang, C. H.-N. (1974). Nocardia coeliaca, Nocardia autotrophica, and the nocardin strain. Int J Syst Bacteriol 24, 54-63.

Hayakawa, M. \& Nonomura, H. (1987). Humic acid-vitamin agar, a new medium for selective isolation of soil actinomycetes. J Ferment Technol 65, 501-509.

Hayakawa, M., Otoguro, M., Takeuchi, T., Yamazaki, T. \& linuma, Y. (2000). Application of a method incorporating differential centrifugation for selective isolation of motile actinomycetes in soil and plant litter. Antonie Van Leeuwenhoek 78, 171-185.

Itoh, T., Kudo, T., Parenti, F. \& Seino, A. (1989). Amended description of the genus Kineosporia, based on chemotaxonomic and morphological studies. Int J Syst Bacteriol 39, 168-173.

Kluge, A. G. \& Farris, J. S. (1969). Quantitative phyletics and the evolution of anurans. Syst Zool 18, 1-32.

Kudo, T., Matsushima, K., Itoh, T., Sasaki, J. \& Suzuki, K. (1998). Description of four new species of the genus Kineosporia: Kineosporia succinea sp. nov., Kineosporia rhizophila sp. nov., Kineosporia mikuniensis sp. nov. and Kineosporia rhamnosa sp. nov., isolated from plant samples, and amended description of the genus Kineosporia. Int J Syst Bacteriol 48, 1245-1255.

Marmur, J. (1961). A procedure for the isolation of deoxyribonucleic acid from microorganisms. J Mol Biol 3, 208-218.

Mesbah, M., Premachandran, U. \& Whitman, W. B. (1989). Precise measurement of the $\mathrm{G}+\mathrm{C}$ content of deoxyribonucleic acid by high-performance liquid chromatography. Int J Syst Bacteriol 39, 159-167.

Minnikin, D. E., O’Donnell, A. G., Goodfellow, M., Alderson, G., Athalye, M., Schaal, A. \& Parlett, J. H. (1984). An integrated procedure for the extraction of bacterial isoprenoid quinones and polar lipids. J Microbiol Methods 2, 233-241.

Nozawa, Y., Sakai, N., Arai, K., Kawasaki, Y. \& Harada, K. (2007). Reliable and sensitive analysis of amino acids in the peptidoglycan of actinomycetes using the advanced Marfey's method. J Microbiol Methods 70, 306-311.

Pagani, H. \& Parenti, F. (1978). Kineosporia, a new genus of the order Actinomycetales. Int J Syst Bacteriol 28, 401-406.

Saito, H. \& Miura, K. (1963). Preparation of transforming deoxyribonucleic acid by phenol treatment. Biochim Biophys Acta 72, 619-629.

Saitou, N. \& Nei, M. (1987). The neighbor-joining method: a new method for reconstructing phylogenetic trees. Mol Biol Evol 4, 406-425.

Shirling, E. B. \& Gottlieb, D. (1966). Methods for characterization of Streptomyces species. Int J Syst Bacteriol 16, 313-340.

Staneck, J. L. \& Roberts, G. D. (1974). Simplified approach to identification of aerobic actinomycetes by thin-layer chromatography. Appl Microbiol 28, 226-231.

Tamura, T. \& Hatano, K. (2001). Phylogenetic analysis of the genus Actinoplanes and transfer of Actinoplanes minutisporangius Ruan et al. 1986 and 'Actinoplanes aurantiacus' to Cryptosporangium minutisporangium comb. nov. and Cryptosporangium aurantiacum sp. nov. Int $J$ Syst Evol Microbiol 51, 2119-2125.

Tamura, T., Nakagaito, Y., Nishii, T., Hasegawa, T., Stackebrandt, E. \& Yokota, A. (1994). A new genus of the order Actinomycetales, Couchioplanes gen. nov., with descriptions of Couchioplanes caeruleus (Horan and Brodsky 1986) comb. nov. and Couchioplanes caeruleus subsp. azureus subsp. nov. Int J Syst Bacteriol 44, 193-203.

Thompson, J. D., Gibson, T. J., Plewniak, F., Jeanmougin, F. \& Higgins, D. G. (1997). The CLUSTAL_X Windows interface: flexible 
strategies for multiple sequence alignment aided by quality analysis tools. Nucleic Acids Res 25, 4876-4882.

Wayne, L. G., Brenner, D. J., Colwell, R. R., Grimont, P. A. D., Kandler, O., Krichevsky, M. I., Moore, L. H., Moore, W. E. C., Murray, R. G. E. \& other authors (1987). International Committee on
Systematic Bacteriology. Report of the ad hoc committee on reconciliation of approaches to bacterial systematics. Int J Syst Bacteriol 37, 463-464.

Willoughby, L. G. (1969). A study on aquatic actinomycetes, the allochthonous leaf component. Nova Hedwigia 18, 45-113. 